\title{
Model Customer Relationship Management of Modern Trade Retail Business
}

\author{
Kullachet Suthinopparrattanakul", Vichit U-on \\ College of Management, Sripatum University, Thailand
}

Copyright $(2016$ by authors, all rights reserved. Authors agree that this article remains permanently open access under the terms of the Creative Commons Attribution License 4.0 International License

\begin{abstract}
The purposes of this paper were to examine the model customer relationship management of modern trade retail business. The target groups were shoppers and members in 6 modern trade stores; Tesco Lotus, Big C, Tops Supermarket, Central Department Store, The Mall, and Home Fresh Mart, in which were total amount of 1,200 persons. The researcher used Multi-Stage-Sampling to collect all data by using questionnaires during September to October 2015 and received 1,200 copies back. Besides, the researcher analyzed the result by using Structural Equation Modeling: SEM. According to this research, IT and Marketing were affected directly to the Capability of Customer Relationship Management, but the knowledge management was not affected directly to the Capability of Customer Relationship Management. However, the Capability of Customer Relationship Management was affected directly to the result of organization management. The knowledge management and Marketing were affected directly to the result of organization management, but IT was not affected directly to the result of organization management. In addition, the result of organization management was affected indirectly from IT and Marketing that corresponded with the research assumption which was specified. But the result of organization management was affected indirectly.
\end{abstract}

Keywords Customer Relationship Management, Technology, Knowledge Management, Market Orientation, Organizational Performance

\section{Introduction}

The retail and wholesale business in Thailand is essential to the national economy. Apart from generating high revenue second only to the industrial sector, these businesses also provide the third highest employment rate after the agriculture and service sectors. Furthermore, retail and wholesale also have direct roles and impacts on the well-being of the people. Therefore, retail business is an economic activity involved in driving the overall economic and social development processes of the country as the driving force behind improvements in people's living standards and quality of life. It acts as a medium for the gathering and distribution of goods from manufacturers to consumers (Institute of Small and Medium Enterprise Development (ISMED)

Thailand's retail business is faced with more intense market conditions and competitions. It has been found that one of today's key problems and barriers to operating a retail business in Thailand is the country's economic situation, which still has not recovered from the slowdown in 2013-2014. This is combined with high level of uncertainty surrounding global economic growth, low agricultural product prices, high household debts, increased production costs and rising living costs such as higher labor, fuel, energy and transportation costs (Economic and Business Projection Center, 2014-2015). Also included is the increased retail business growth with growing number of branches. Naturally, there are more business competitions, rapid changes, increased customer expectations and reduced customer loyalty to businesses (ASTV, Online Manager, 2015). Due to the aforementioned problems, operators of traditional trade and modern trade need to come up with marketing strategies that will help their businesses grown and survive to meet consumer demands and performance (Institute of Small and Medium Enterprise Development). As a result, customer relationship management (CRM) has been heavily employed. CRM is considered as another marketing strategy that has been accepted as essential to attracting more customers and maintaining existing customers while building customer satisfaction and loyalty (Day \& Van den Bulte. (2002), Stan Maklan and Simon Knox (2009), Mamoun N. Akroush et al. (2011), Yonggui Wang \& HuiFeng (2012), Dennis Herhausen and Marcus Scho“gel (2013), Jifeng Mu (2013), H.Y. Lam et al. (2013) and Ibrahim Elbeltagi et al. (2014). This leads to better financial performance and improved competitiveness as customer needs are met (Silvia Martelo Landrogues et al. (2011), Moustafa Battor \& Mohamed Battour (2013), Jifent Mu (2013), Ibrahim Elbeltagi et al. (2014) and Daniel D. Cox and Scott McLeod (2014). In this study, the researcher employed the System Theory of Bouldwing Bertalunffy 
(1920) as the conceptual framework. The aforementioned theory states that management resulting from the integration of duties, activities and management and strategic planning composed of the input stage, conversion or transformation stage, output stage and feedback can be used to benefit analysis while improving the input stage and examination results with consideration given to external environment in adaptation of models of improvement in the customer relationship management skills of modern traders. The researcher focused on exploring the development of customer relationship management skills and customer relationship management skills that influenced business performance as well as the performance of customer relationship management businesses.

The researcher discovered from literature review that, apart from measuring customer relationship management by financial performance, marketing performance and environmental performance could also be measured (Kim et al. (2003), Basar Oztays et al. (2011), Paul Harrigan et al.
(2012), Molan Kim et al. (2012), Majidul Islam et al. (2012), H.Y. Lam et al. (2014) and Dennis Herhausen and Marcus Schögel (2014)

\section{Literature Review}

\section{Customer Relationship Management}

The researcher has summarized the meaning and/or the definition of a customer relationship management is the strategy which focuses on building relationship between business and customers to leverage the strong long-term relationship and maintaining customer relationship, in order to respond to the personal or organizational satisfactions, to build the loyalty, to maintain existing customers, and to introduce new customers which lead to the ability to make a good profit.

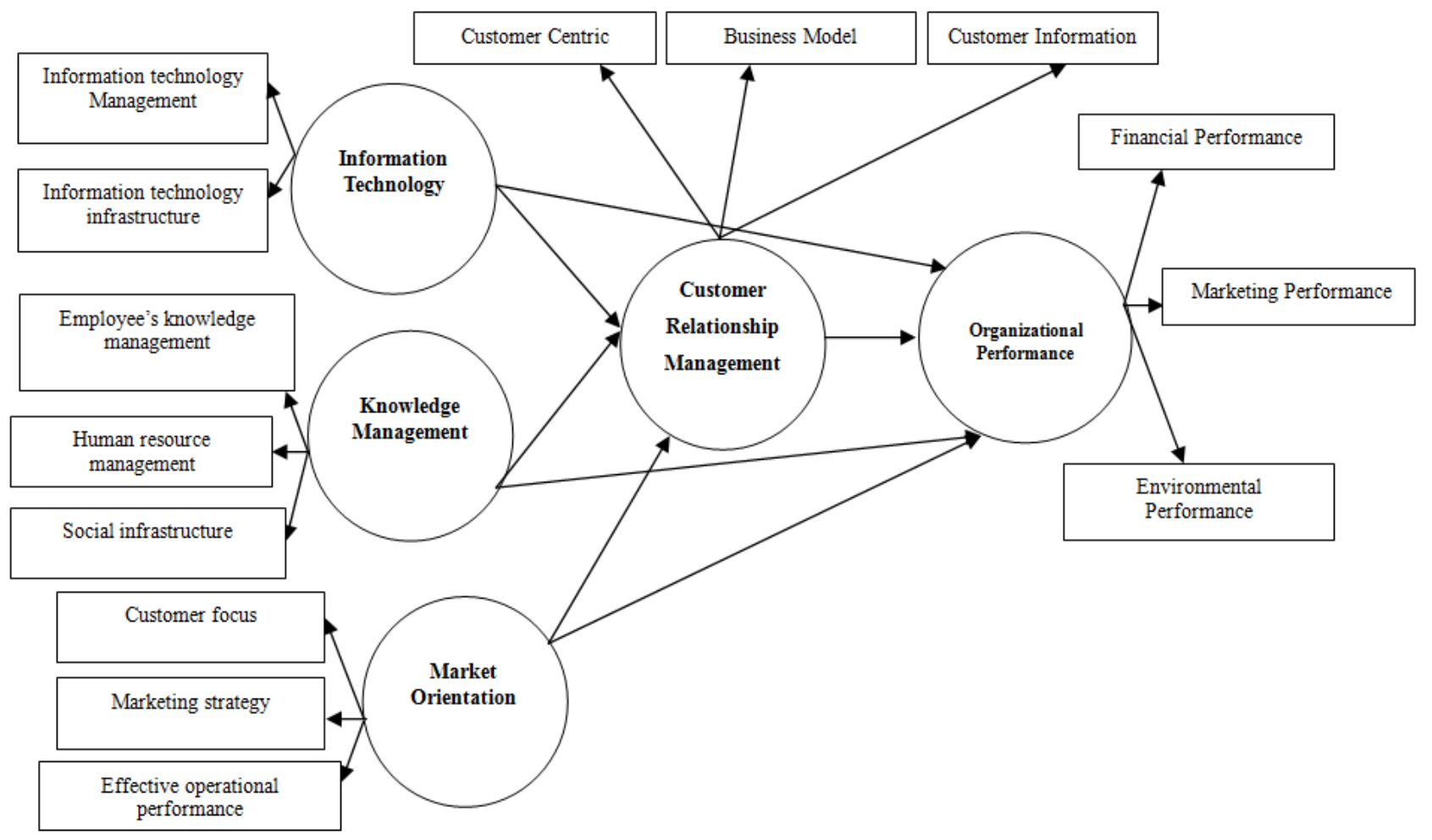

Figure 1. Research Framework Customer Relationship Management Business Model 
The purpose of the conceptual framework was to study Customer Relationship Model .According to Figure 1, it was a literature review before collect the data. The researcher reviewed the literature from International and also from Thai research databases. The researcher developed the conceptual framework by determining theoretical framework for this researcher in 3 parts as: (1) Customer Relationship Business Model; Information Technology variable by using the theoretical ideas from Chen \& Ching (2002) and Vanessa Zheng (2011). Its components consisted of 'Knowledge Management Information Technology' and Information Technology Infrastructure. The researcher uses the concepts from research papers and articles of Ikujiro Nonaka (1991) and Chun Wei Choo and Rivadávia Correa Drummond de Alvarenga Neto (2010) for 'Knowledge Management'. It composes of knowledge management, human resources management and social infrastructure. 'Market Orientation' variable considering the ideas of strategy focus, structure management, and operational co-operate focus within organization. (2) 'Customer Relationship Management' the researcher used the concept of Day \& Van den Bulte (2002). It consisted of customer focus by Stan Maklan and Simon Knox (2009), Yonggui Wang \& Hui Feng (2012), knowledge management to build customer relationship Mamoun N. Akroush et al. (2011), Silvia Martelo Landroguezet al.(2011) and information technology for building the relations, and Mamoun N. Akroush et al.(2011), Yonggui Wang Feng
(2012). The last part (3) the outcome of customer relationship management effected on organization performance. The researcher used the concept of Kim et al., (2003) and Mamoun N. Akroush et al. (2011) consisted of two sub parts as: 1) financial performance which measured an outcome from financial side by comparing the quantitative performance or income statement of an organization Kim et al. (2003), Basar Oztaysi (2011), Mohammad Ali Shafia et al. (2011), Mamoun N. Akroush et al. (2011), Molan Kim et al (2011), and 2) marketing performance, the KPI of marketing was measured by customers. Highlight on creating customer's satisfaction, building relations, way of life, values and bringing all benefits to the society, community, environmental friendly stated by Kim et al., (2003), Basar Oztays et al. (2011), Paul Harrigan et al. (2012), Molan Kim et al. (2012), Majidul Islam et al. (2012), H.Y. Lam et al. (2014) and Dennis Herhausen and Marcus Scho"gel (2014).

For the aforementioned reasons, the researcher conducted a study on the development of customer relationship management skill models and customer relationship management skills that influenced business performance that would allow access to improvements to customer relationship management models that lead to competitive advantage and better business performance in modern trade.

\begin{tabular}{|c|c|c|c|c|c|c|c|c|c|c|c|c|c|c|}
\hline $\begin{array}{l}\text { Resurbem } \\
\text { Yex }\end{array}$ & $\begin{array}{l}\text { Cuntewer } \\
\text { Cortix }\end{array}$ & $\begin{array}{l}\text { Bumeta } \\
\text { Model }\end{array}$ & 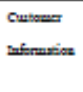 & 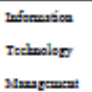 & 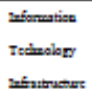 & 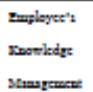 & $\begin{array}{l}\text { Mruma } \\
\text { reatrab } \\
\text { Mamagrant }\end{array}$ & 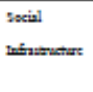 & $\begin{array}{l}\text { Cultomer } \\
\text { Pocus }\end{array}$ & $\begin{array}{l}\text { Starketing } \\
\text { Soratey }\end{array}$ & $\begin{array}{l}\text { offection } \\
\text { Opernion } \\
\text { Peformanee }\end{array}$ & 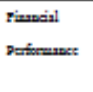 & $\begin{array}{l}\text { Sariecieg } \\
\text { Deforemener }\end{array}$ & 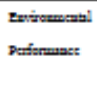 \\
\hline $\begin{array}{l}\text { Chan A Cling } \\
\text { (2002) }\end{array}$ & $\sqrt{7}$ & $\checkmark$ & $\checkmark$ & $\checkmark$ & $\checkmark$ & $\gamma$ & $\checkmark$ & $\checkmark$ & $\checkmark$ & & & $\checkmark$ & $\checkmark$ & \\
\hline $\begin{array}{l}\text { Vereus these } \\
\text { (2001) }\end{array}$ & $\bar{\gamma}$ & $\bar{\gamma}$ & $\checkmark$ & $\checkmark$ & $\checkmark$ & $\checkmark$ & 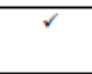 & $\checkmark$ & $\checkmark$ & $\checkmark$ & & $\checkmark$ & $\checkmark$ & $\bar{r}$ \\
\hline $\begin{array}{l}\text { IlajizeNterwia } \\
(1991)\end{array}$ & & $\checkmark$ & $\checkmark$ & $\checkmark$ & $\checkmark$ & $\checkmark$ & $\checkmark$ & $\checkmark$ & & $\checkmark$ & $\checkmark$ & & & \\
\hline $\begin{array}{l}\text { Chra weichoo } \\
\text { (2010) }\end{array}$ & & $\checkmark$ & $\checkmark$ & $\checkmark$ & $\checkmark$ & $\checkmark$ & 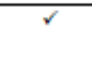 & $\checkmark$ & & $\checkmark$ & $\checkmark$ & & $\checkmark$ & \\
\hline $\begin{array}{l}\text { Dxy } \approx V x=d a \\
\text { Dube (2002) }\end{array}$ & $\checkmark$ & $\checkmark$ & $\checkmark$ & $\checkmark$ & $\checkmark$ & & 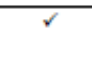 & $\checkmark$ & $\checkmark$ & $\checkmark$ & $\checkmark$ & $\checkmark$ & $\checkmark$ & $\checkmark$ \\
\hline Yan stishe (2009) & $\checkmark$ & $\checkmark$ & $\checkmark$ & $\checkmark$ & $\checkmark$ & & & & $\checkmark$ & $\checkmark$ & $\checkmark$ & $\checkmark$ & $\checkmark$ & \\
\hline $\begin{array}{l}\text { Teatri Wuge \& } \\
\text { Muirtag (2012) }\end{array}$ & $\checkmark$ & $\checkmark$ & $\checkmark$ & $\checkmark$ & $\checkmark$ & & & & $\checkmark$ & $\checkmark$ & $\checkmark$ & $\checkmark$ & $\checkmark$ & \\
\hline 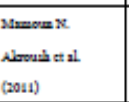 & $\checkmark$ & $\checkmark$ & $\checkmark$ & $\checkmark$ & $\checkmark$ & $\checkmark$ & $\checkmark$ & $\checkmark$ & $\checkmark$ & $\checkmark$ & $\checkmark$ & $\checkmark$ & $\checkmark$ & \\
\hline 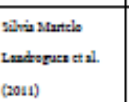 & $\checkmark$ & $\checkmark$ & $\checkmark$ & $\checkmark$ & $\checkmark$ & $\checkmark$ & & $\checkmark$ & $\checkmark$ & $\checkmark$ & $\gamma$ & $\checkmark$ & $\checkmark$ & $\checkmark$ \\
\hline xim et al, (2009s) & 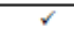 & $\checkmark$ & $\checkmark$ & $\checkmark$ & $\checkmark$ & $r$ & 8 & $\checkmark$ & $\checkmark$ & $\checkmark$ & $\checkmark$ & $\checkmark$ & $\checkmark$ & $\checkmark$ \\
\hline 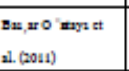 & $\bar{V}$ & $\checkmark$ & $\checkmark$ & $\checkmark$ & $\checkmark$ & $\checkmark$ & $\checkmark$ & $\checkmark$ & $\checkmark$ & $\checkmark$ & $\bar{r}$ & $\checkmark$ & $\checkmark$ & $\bar{r}$ \\
\hline $\begin{array}{l}\text { Pul Murigun et 21 } \\
\text { (2012) }\end{array}$ & $\checkmark$ & $\checkmark$ & $\checkmark$ & $\checkmark$ & $\checkmark$ & $\checkmark$ & $\checkmark$ & $\checkmark$ & $\checkmark$ & $\checkmark$ & $\checkmark$ & $\checkmark$ & $\checkmark$ & $\checkmark$ \\
\hline $\begin{array}{l}\text { Moshan Xine et al. } \\
\text { (20012) }\end{array}$ & $\checkmark$ & $\checkmark$ & $\checkmark$ & $\checkmark$ & $\checkmark$ & $\checkmark$ & 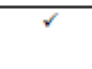 & $\checkmark$ & $\checkmark$ & $\checkmark$ & $\checkmark$ & $\checkmark$ & $\checkmark$ & $\checkmark$ \\
\hline $\begin{array}{l}\text { Mavidal wilum et al } \\
\text { (20012) }\end{array}$ & $\checkmark$ & $\checkmark$ & $\checkmark$ & $\checkmark$ & $\bar{\checkmark}$ & $\nabla$ & $\bar{v}$ & $\checkmark$ & $\checkmark$ & $\checkmark$ & $\checkmark$ & $\checkmark$ & $\checkmark$ & $\bar{\checkmark}$ \\
\hline $\begin{array}{l}\text { r.r.2= et al. } \\
(2014)\end{array}$ & $\checkmark$ & $\checkmark$ & $\checkmark$ & $\checkmark$ & $\bar{v}$ & $\checkmark$ & $\bar{\gamma}$ & $\checkmark$ & $\checkmark$ & $\checkmark$ & $\checkmark$ & $\checkmark$ & $\checkmark$ & $\checkmark$ \\
\hline $\begin{array}{l}\text { Demin Mraturax } \\
\operatorname{mad}(2014)\end{array}$ & $\checkmark$ & $\checkmark$ & $\checkmark$ & $\checkmark$ & $\bar{v}$ & $\checkmark$ & $\bar{v}$ & $\checkmark$ & $\bar{\checkmark}$ & $\bar{\checkmark}$ & $\checkmark$ & $\checkmark$ & $\checkmark$ & $\bar{\checkmark}$ \\
\hline
\end{tabular}




\section{Research Objectives}

The objects of the research entitled "Improving Customer Relationship Management Skill Models for Modern Trades" were to study the customer relationship management skill models for modern trade Retail Business.

\section{Research Hypothesis}

The researcher set the following research hypotheses for this study on developing customer relationship management skill models in modern trade:

Hypothesis 1 - knowledge of information technology had direct effect on customer centric business.

Hypothesis 2 - knowledge management for organizations had direct effect on customer centric business.

Hypothesis 3 - strategies for customer focus (SFCF) had direct effect on customer centric business.

\section{Expected Benefits}

\section{Academic Benefits}

Academic discoveries on explaining the development of customer relationship management skill models and customer relationship management skill models that influence the performance of modern trade organizations will be gained.

\section{Professional or Practical Benefits}

(1) Executives responsible for organizational planning and policies will gain insight into the development of customer relationship management skills in modern trade and can apply the research findings as data to accompany considerations of plans to develop suitable models for use as instruments in improving customer relationship management skills leading to business competitive advantages.

(2) Executives will be able to foresee performance outcomes resulting from the customer relationship management skills of modern trade.

\section{Population}

Researchers determined the study scopes which covered 3 categories of new retail businesses. These businesses were categorized into 3 groups which were Hypermarket, Supermarket and Department Store. The Hypermarket consisted of both Lotus and Big C. The Supermarket included Tops Supermarket and Home Fresh Mart. The Department Store category consists of Central and The Mall Department Stores.

\section{Sample}

To get the right sample size from represents good and efficient information providers, researchers determined the scope of our study area. It's the 3 categories of new retail businesses customers in the Hypermarket, Supermarket and Department Store. Each category had the sample size as follows:

\begin{tabular}{|c|c|c|}
\hline Member Retail Business & Total & Sample Size \\
\hline \multicolumn{3}{|l|}{ Hypermarket } \\
\hline Tesco Lotus & $12,000,000$ & 270 \\
\hline \multirow[t]{2}{*}{ Big C } & $5,800,000$ & 130 \\
\hline & $17,800,000$ & 400 \\
\hline \multicolumn{3}{|l|}{ Supermarket } \\
\hline Tops Supermarket & $5,100,000$ & 276 \\
\hline Home Fresh Mart & $2,300,000$ & 124 \\
\hline รวม & $7,400,000$ & 400 \\
\hline \multicolumn{3}{|l|}{ Department Store } \\
\hline The Mall & $2,300,000$ & 128 \\
\hline Central Department Store & $4,900,000$ & 272 \\
\hline รวม & $7,200,000$ & 400 \\
\hline
\end{tabular}


Members of new retail businesses in each category includes

Determining Sample Size

We determine the Sample Size by using the Yamane (1967) formula

Research Design

Formula $n=\frac{N}{1+N E^{2}}$

Of which

$\mathrm{n}$ is the sample size

$\mathrm{N}$ is the population size of these 7 companies

$\mathrm{e}$ is the level of precision $(0.05)$

Hypermarket $\mathrm{n}=\frac{17,800,000}{1+17,800,000(0.05)^{2}}$

$$
\mathrm{n}=400
$$

Supermarket $\mathrm{n}=\frac{7,400,000}{1+7,400,000(0.05)^{2}}$

$\mathrm{n}=400$
Departmentstoret $\mathrm{n}=\frac{7,200,000}{1+7,200,000(0.05)^{2}}$

$$
\mathrm{n}=400
$$

Therefore, the sample size for each group was 400 samplings in each category. So, there were totally 1,200 samplings

\section{Research Design}

In this study, the researcher used Exploratory Factor Analysis : EFA to modify model from previous research “Model Development Capability of Customer Relationship Management Modern Trade " The researcher used the System Theory of Bouldwing Bertalunffy (1920), which stated that management resulting from the integration of duties, activities and management and strategic planning composed of the input stage, conversion or transformation stage, output stage and feedback used in to benefit analysis to improve the input stage and examine results with considerations to external environments in adaptations of models of improvements to customer relationship management skills of modern trade. The researcher focused on studying the development of customer relationship management skill models for modern trade capable of completely answer research questions. Furthermore, the researcher employed a mixed method composed of qualitative and quantitative research carried out in tandem. In the qualitative research, the researcher gathered primary data that resulted from an opinion survey conducted in an association, namely, Thai Retailers' Association, Dunnhumby (Thailand) Co., Ltd., Symphony EYC (Thailand) and online information, including user information of six modern trade retailers, composed of Tesco Lotus, Big C, Central Department Store, The Mall, Tops and Home Fresh Mart with the total membership at 30,100,000 people in addition to studying the development of customer relationship management skills of modern trades and develop a framework along with questionnaires as instruments for conducting the research. The quality of the research instruments was tested by five qualified experts on retails and thesis advisory professors in order to extract suitable variables. Priority was placed on the first qualitative research, and the questionnaires were tried out on sixty subjects who were not part of the sample group in order to determine the suitability of the variables studied. Next, data collection was commenced. Questionnaires were used on 1,200 modern trade service users and modern trade members composed of hypermarkets, supermarkets and department stores, which were highly competitive retail businesses that contained a membership system (Thai Retailers' Association) composed of Tesco Lotus, Big C, Tops Supermarket, Central Department Store, The Mall and Home Fresh Mart. Structural Equation Modeling (SEM) was used as the statistical technique for testing for causal relationships. Data were analyzed using LISREL. The research objectives were as follows: (1) to study the customer relationship management skill models for modern trade and (2) to develop customer relationship management skill models that influenced business performance. Once knowledge was obtained on development of customer relationship management skill models for modern trades, the second qualitative research commenced for which the opinions of modern trade executives were interviewed again in order to switch from a foreign context to a context of the Thai people and in order to confirm with certainty that the aforementioned variables influenced the customer relationship management of modern trades in order to achieve set objectives of the research.

The researcher analyzed the relationship model between customer centric business in relationship management, Knowledge of appropriate technology, Knowledge management for organizations, Strategies for customer focus and Evaluation of the organization, overall model performance of modern trades using the maximum likelihood method and found that the Goodness of Fit Index remained inconsistent with empirical information or was not concurrent with set criteria when evaluating based on the $\chi^{2}$ $=185.07, \mathrm{df}=34, \mathrm{p}$-value $=0.000, \mathrm{CFI}=1.00, \mathrm{GFI}=0.99$, AGFI $=0.97, \quad$ RMSEA $=0.04$ and $\mathrm{SRMR}=0.01$ values. The researcher presented the overall Goodness of Fit Index analysis of models below: 


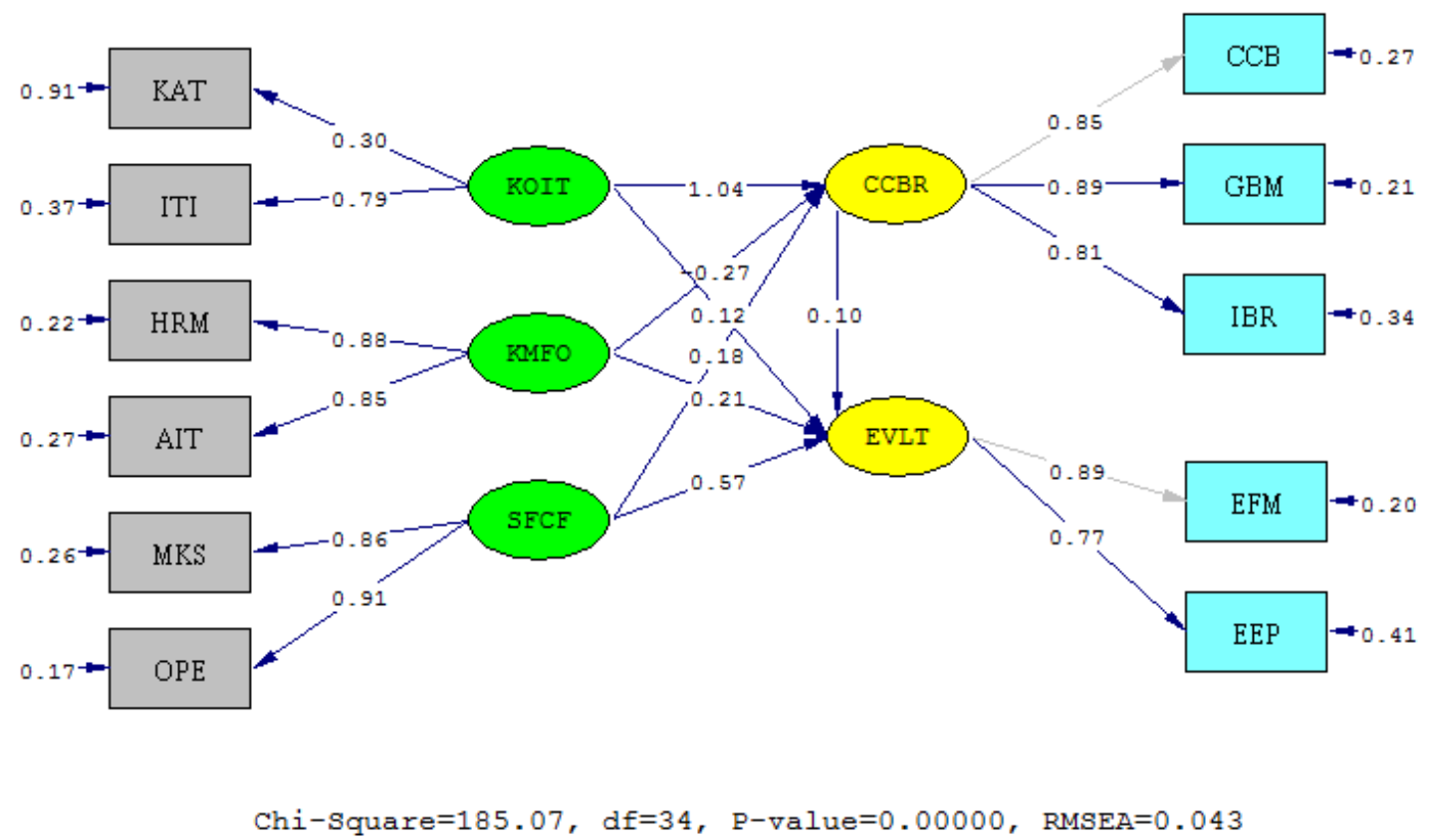

Figure 2. Shows the analysis of the Goodness of Fit Index for the overall models (before discrepancy relationship adjustments).

KOIT $=$ Knowledge of information technology of Modern Trade Retail Business

KMFO $=$ Knowledge management for organizations of Modern Trade Retail Business

SFCF $=$ Strategies for customer focus of Modern Trade Retail Business

$\mathrm{CCBR}=$ Customer centric business to create positive relationships of Modern Trade Retail Business

EVLT $=$ Evaluation of the organization of Modern Trade Retail Business

According to Figure 2 before finished collecting the data from 1,200 people the researcher got this information to show the analysis of the Goodness of Fit Index for the overall models.

According to Table 1, the overall relationship model between customer centric business in relationship management, Knowledge of appropriate technology, Knowledge management for organizations, Strategies for customer focus and Evaluation of the organization, overall model performance of modern trades developed by the researcher based on related concepts and theories. Consistency and fitness is lacked with empirical information. Calculated statistical data were used in considerations, namely $\chi^{2}=185.07, \mathrm{df}=34, \mathrm{p}$-value $=0.000, \mathrm{CFI}=1.00$, $\mathrm{GFI}=0.99$, AGFI $=0.97, \mathrm{RMSEA}=0.04$ and $\mathrm{SRMR}=0.01$; some key statistical values failed to pass set criteria
(Joreskog; \& Sorbom, 1996).

Hence, the researcher modified the model with consideration given to the model parameter adjustment recommendations from the model modification indices (MI). Next, parameters were adjusted by consent to relax preliminary agreements for discrepant values to correlate until the Goodness of Fit Index showed consistency with empirical information. The overall analysis results of the Goodness of Fit Index of the post-adjustment model by the researcher allowed the analysis results presentation in Table 2, which shows the overall analysis of the Goodness of Fit Index of the model with post-model adjustments to obtain model fitness with the empirical information. In addition, Figure 3 shows the overall analysis of the model fitness index after modification.

Table 1. Shows the analysis of Goodness of Fit Index for the overall models.

\begin{tabular}{cccc}
\hline Goodness of Fit Index & Criteria & $\begin{array}{c}\text { Measurable Index } \\
\text { Value }\end{array}$ & Results \\
\hline$\chi^{2}$ df $(185.07 / 34)$ & $<2.00$ & 5.44 & No Pass \\
CFI & $\geq 0.95$ & 1.00 & Pass \\
GFI & $\geq 0.95$ & 0.99 & Pass \\
AGFI & $\geq 0.90$ & 0.97 & Pass \\
RMSEA & $<0.05$ & 0.04 & Pass \\
SRMR & $<0.05$ & 0.01 & Pass \\
\hline
\end{tabular}




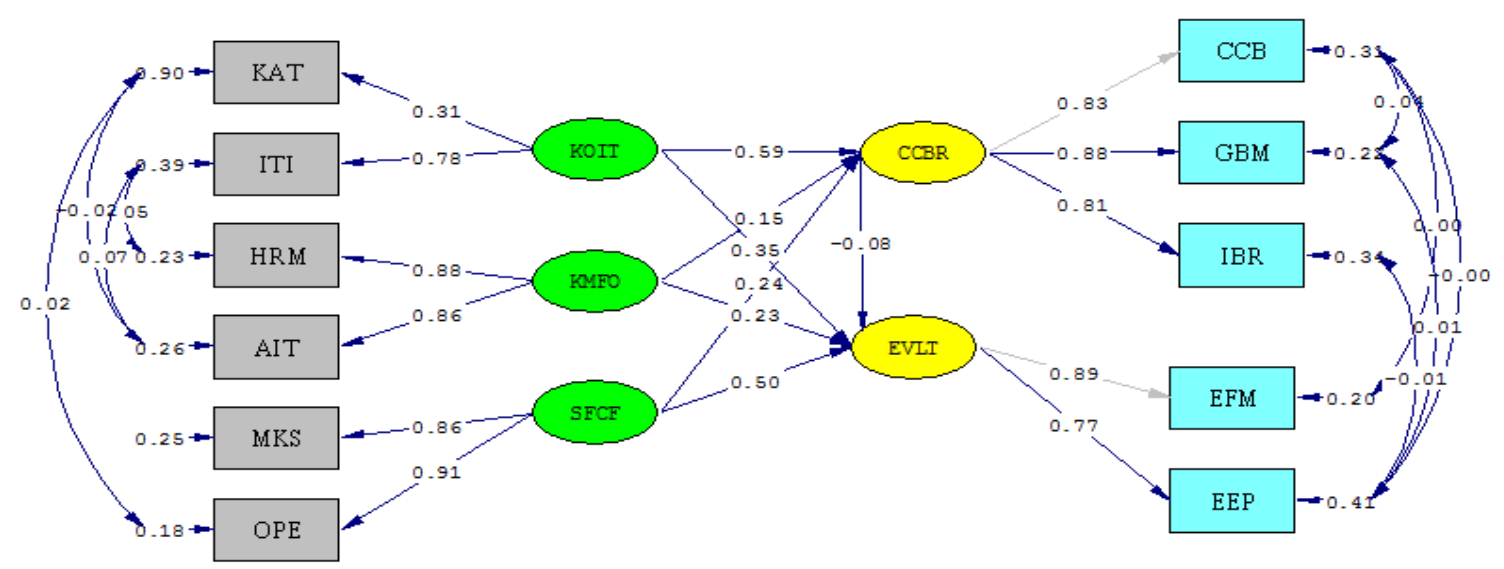

Chi-Square $=23.13, \mathrm{df}=15, \mathrm{P}$-value $=0.08139, \mathrm{RMSEA}=0.015$

Figure 3. Shows the overall analysis of model fitness (post-discrepancy relationship adjustment

According to Figure 3 post finished collecting the data form 1,200 people the researcher got this information to show the overall analysis of model fitness.

Table 2. Shows the overall analysis of model fitness post-model model modification.

\begin{tabular}{cccc}
\hline Fitness Index & Criteria & Measured Index & Evaluation \\
\hline$\chi^{2}$ dff $(23.13 / 15)$ & $<2.00$ & 1.54 & Pass \\
CFI & $\geq 0.95$ & 1.00 & Pass \\
GFI & $\geq 0.95$ & 1.00 & Pass \\
AGFI & $\geq 0.90$ & 0.99 & Pass \\
RMSEA & $<0.05$ & 0.02 & Pass \\
SRMR & $<0.05$ & 0.01 & Pass \\
\hline
\end{tabular}

According to Table 2, when considering the model fitness indices, the overall model was found to fit with the empirical information with all six fitness indices passing the acceptance criteria with the following index values: $\chi^{2} / \mathrm{df}=$ $1.54, \mathrm{CFI}=1.00, \mathrm{GFI}=1.00, \mathrm{AGFI}=0.99, \mathrm{RMSEA}=0.02$ and SRMR $=0.01$. Therefore, it can be concluded that the structural equation model was suitable. The fitness with empirical information can be explained as follows:

(1) Relative Chi-Square $\left(\chi^{2} / \mathrm{df}\right)$ of 1.54 shows that the model fit with empirical information because the relative Chi-Square $\left(\chi^{2} / \mathrm{df}\right)$ value was less than 2.00 .

(2) The comparative fit index (CFI) was 1.00 , showing that the model had comparative fitness because CFI was 0.90 and up.

(3) The Absolute Fit Index used by the researcher in two indices obtained 0.99 for the Goodness of Fit Index (GFI) and 1.00 for Adjusted Goodness of Fit Index (AGFI), which showed that the model was fit with empirical information because GFI and AGFI scores ranged between 0-1 and accepted GFI and AGFI were above 0.90 .

(4) The root mean square error of approximation (RMSEA) obtained a score of 0.02 , which meant that the model was rather fit with empirical information because the RMSEA score was less than 0.05 or ranged from 0.05 to 0.08 .

(5) The index used by the researcher in consideration of the discrepancy fit index was the standardized root mean square residual (SRMR), which equaled 0.01, thereby showing that the model fit with the empirical information because the square was below 0.05 .

\section{Path Analysis}

1. Influence causal analysis of the development of customer relationship management skills of modern trades:

The researcher conducted an influence causal analysis of the development of customer relationship management skills of modern trades in order to answer research questions and hypotheses. The researcher presented the direct effects (DE), indirect effects (IE) and total effects (TE). The results of the analysis can be discussed as follows:

According to the influence causal analysis of model variables of the development of customer relationship management skills of modern trades (direct, indirect and total effects) based on the research hypotheses and empirical information, the aforementioned model was fit with empirical information. 
Table 3. Shows the causal influence analysis of variables in the model of customer relationship management skills of modern trades.

\begin{tabular}{|c|c|c|c|c|c|c|}
\hline \multirow{3}{*}{ Causal Factor } & \multicolumn{6}{|c|}{ Outcome Factor } \\
\hline & \multicolumn{3}{|c|}{ CCBR } & \multicolumn{3}{|c|}{ EVLT } \\
\hline & TE & IE & TE & IE & TE & IE \\
\hline \multirow[t]{3}{*}{ KOIT } & $0.59^{*}$ & - & $0.59^{*}$ & 0.30 & -0.05 & 0.35 \\
\hline & $(0.25)$ & - & $(0.25)$ & $(0.15)$ & $(0.11)$ & $(0.26)$ \\
\hline & 2.41 & - & 2.41 & 1.95 & -0.42 & 1.36 \\
\hline \multirow[t]{3}{*}{ KMFO } & 0.15 & - & 0.15 & $0.22^{* * *}$ & -0.01 & $0.23^{* *}$ \\
\hline & $(0.13)$ & - & $(0.13)$ & $(0.07)$ & $(0.03)$ & $(0.08)$ \\
\hline & 1.09 & - & 1.09 & 3.26 & -0.44 & 3.07 \\
\hline \multirow[t]{3}{*}{ SFCF } & 0.24 & - & 0.24 & $0.48^{* *}$ & -0.02 & $0.50^{* *}$ \\
\hline & $(0.20)$ & - & $(0.20)$ & $(0.13)$ & $(0.03)$ & $(0.11)$ \\
\hline & 1.20 & - & 1.20 & 3.65 & -0.65 & 4.33 \\
\hline \multirow[t]{3}{*}{ CCBR } & - & - & - & -0.08 & - & -0.08 \\
\hline & - & - & - & $(0.17)$ & - & $(0.17)$ \\
\hline & - & - & - & -0.48 & - & -0.48 \\
\hline \multicolumn{7}{|c|}{ Statistics Chi-Square $=23.13, \mathrm{df}=15, \mathrm{P}=0.08139, \mathrm{GFI}=1.00, \mathrm{AGFI}=1.00, \mathrm{SRMR}=0.01$} \\
\hline Variable & CCB & GBM & IBR & EFM & EEP & \\
\hline Accuracy & 0.69 & 0.78 & 0.66 & 0.80 & 0.59 & \\
\hline Variable & KAT & ITI & HRM & AIT & MKS & OPE \\
\hline Accuracy & 0.10 & 0.61 & 0.77 & 0.74 & 0.75 & 0.82 \\
\hline Variable & CCBR & EVLT & & & & \\
\hline Accuracy & 0.89 & 0.93 & & & & \\
\hline Variable Structure Equation & CCB & GBM & IBR & EFM & EEP & \\
\hline R Square & 0.69 & 0.78 & 0.66 & 0.80 & 0.59 & \\
\hline \multicolumn{7}{|c|}{ Correlation Matrix between Hidden Variables } \\
\hline Hidden Variable & CCBR & EVLT & KOIT & KMFO & SFCF & \\
\hline CCBR & 1.00 & & & & & \\
\hline EVLT & 0.89 & 1.00 & & & & \\
\hline KOIT & 0.94 & 0.93 & 1.00 & & & \\
\hline KMFO & 0.87 & 0.89 & 0.88 & 1.00 & & \\
\hline SFCF & 0.90 & 0.94 & 0.92 & 0.86 & 1.00 & \\
\hline
\end{tabular}

Remarks: $*<.05, \quad * *<.01$

The table shows the consistency text of the causal model of the development of customer relationship management skills of modern trades and empirical information. According to the findings, the model was consistent with empirical information. Considerations were based on statistics used to test for consistency between the model and empirical information such as Chi-Square (23.13), degree of freedom equal to 15 , probability (p) equal to 0.08139 . In other words, the Chi-Square score was different from zero without statistical significance, showing that the primary hypothesis that the causal model of the development of customer relationship management skills of modern trades was developed was fit with empirical information, which concurred with the analysis where the Goodness of Fit Index (GFI) was 1.00, the Adjusted Goodness of Fit Index (AGFI) was 0.99 , which approached 1 , and the Standard Root Mean Square Residual (SRMR) equaled 0.01, which approached zero. The aforementioned details are discussed in detail by the researcher in the findings of the analysis of the fitness of the model of the development of customer relationship management of modern trades. When looking at the score of the observed variables, it is found that the observed variables had scores ranging from $0.10-0.82$ with the highest variable was Operational efficiency (OPE) at 0.82 , followed by the evaluation of financial performance and marketing (EFM) with score of 0.80 and Good business management (GBM) with a score of 0.78 , whereas the variable with the least variable was knowledge of appropriate technology (KAT) with a score of 0.10 .

For the predictive coefficient $\left(\mathrm{R}^{2}\right)$ of the structural equation with hidden variables, the predictive coefficient score $\left(R^{2}\right)$ of the Evaluation of the organization was 0.93 . Furthermore, the predictive coefficient $\left(\mathrm{R}^{2}\right)$ for customer centric business in relationship management was 0.89 .

A summary can be shown as follows:

(1) knowledge of information technology (KOIT) had direct positive effects on customer centric business to create positive relationships (CCBR) with a direct effect size of 0.59 , statistical significance at .05 .

(2) knowledge management for organizations (KMFO) had direct positive effects on customer centric business to create positive relationships (CCBR) with a direct effect size of 0.15 , without statistical significance.

(3) strategies for customer focus (SFCF) had direct positive effects on customer centric business to create 
positive relationships (CCBR) with a direct effect size of 0.24 , without statistical significance.

(4) knowledge of information technology (KOIT) had direct positive effects on evaluation of the organization (EVLT) with a direct effect size of 0.35 , without statistical significance.

(5) knowledge management for organizations (KMFO) had direct positive effects on evaluation of the organization (EVLT) with a direct effect size of 0.23 , statistical significance at .01 .

(6) strategies for customer focus (SFCF) had direct positive effects on evaluation of the organization (EVLT) with a direct effect size of 0.50 , statistical significance at .01 .

(7) knowledge of information technology (KOIT) , knowledge management for organizations (KMFO) and strategies for customer focus (SFCF) had indirect positive effects on evaluation of the organization (EVLT) through customer centric business to create positive relationships (CCBR) with indirect effect sizes of $0.05,-0.01$ and -0.02 , without statistical significance.

\section{Discussion of the Findings}

The findings of the research titled "Improving Customer Relationship Management Skill Models for Modern Trades" can be discussed by the hypotheses of the research as follows:

\section{Information technology had direct effects}

On the customer relationship management. Modern trade can make relationship with their customer by implementing a proper information system to gather relevance information of customer while shopping (Chen \& Ching, 2002) and Coltman et al. (2010)

\section{Knowledge management had direct effects}

On the customer centric business. Human resource management, information technology, and proper knowledge management environment will support organization member to further innovate and develop what they learn to benefit organization Ikujiro Nonaka (1991).

\section{Strategies for customer focus (SFCF) had}

Direct effect on customer centric business. Gartering customer demand, expectation and preferences lead to create marketing strategic. Strategies for customer focus and operation efficiency can bring quality and competitive effect over competition, acquire customer satisfaction, loyalty which leads to business expansion and sustainability of the organization Deshpande \& Webster (1989).

\section{Research Limitations}

The present research had three following significant limitations:

\section{The researcher collected data on the}

Development of customer relationship management skills of modern trades from years 2014-2015, a time when Thailand was caught in political unrest, fluctuating economic conditions and natural disasters such as seasonal changes and droughts, all of which affected retail and wholesale businesses in Thailand, which generate large revenues for the country, and affected the overall income of retail and wholesale businesses.

\section{In the present research, the researcher}

Explored the concepts and theories with a review of relevant literature from secondary sources from domestic and foreign literature. However, primary focus was put on foreign literature to obtain the basic knowledge for conduct the research and developing the research conceptual framework in order to study the development of models for customer relationship management skills of modern trades. People who intend to adapt the findings of the research must take the aforementioned limitation into consideration.

3. In this research, the researcher collected

Data by using questionnaires containing modern trades composed of hypermarkets, supermarkets and department stores, which are the most competitive retailers with memberships (Thai Retailers' Association). There were six businesses, namely, Tesco Lotus, Big C, Tops Supermarket, Central Department Store, The Mall and Home Fresh Mart. Data was collected from the members of the modern trades, who were stakeholders and persons who had awareness of information details that benefited business in addition to being the recipients of services. Therefore, the aforementioned group was the most suitable group for providing data.

\section{REFERENCES}

[1] Abdul alem Mohammad, Basri bin Rashid and Shaharuddin bin Tahir. (2013) "Assessing the influence of customer relationship management (CRM) dimensions on organization performance an emperical study in the hotel industry", Journal of Hospitality and Tourism Technology, Vol. 4 No. 3, 2013, pp. 228-247.

[2] Akroush, M., Dahiyat, S., Gharaibeh, H., \& Abu-Lail, B. (2011). Customer relationship management implementation. International Journal of Commerce and Management, 21(2), 158-190.

[3] Awasthi, P., \& Sangle, P. (2012). Adoption of CRM technology in multichannel environment: A review (20062010). Business Process Management Journal, 18(3), 445-471.

[4] Battor, M., \& Battour, M. (2013). Can organizational learning foster customer relationships? Implications for performance. The Learning Organization, 20(4/5), 279-290. 
[5] Basar Oztays I \& Selime Sezgin \& Ahmet Fahri Ozok. (2011). "A measurement tool for customer relationship management Processes", Industrial Management \& Data Systems, Vol. 111 No. 6, 2011, pp. 943-960.

[6] Cacciolatti, L., \& Fearne, A. (2013). Marketing intelligence in SMEs: Implications for the industry and policy makers. Marketing Intelligence \& Plan Marketing Intelligence \& Planning, 31(1), 4-26.

[7] Christos Sarmaniotis, Costas Assimakopoulos and Eugenia Papaioannou. (2013). "Successful implementation of CRM in luxury hotels: determinants and measurements", Euro Med Journal of Business, Vol. 8 No. 2, 2013, pp. 134-153.

[8] Chotekorakul, W., \& Nelson, J. (2013). Customer orientation, merchandising competencies, and financial performance of small fashion retailers in Bangkok. Journal of Fashion Marketing and Management, 17(2), 225-242.

[9] Choo, C., \& Rivadávia Correa Drummond De Alvarenga Neto. (2010). Beyond the ba: Managing enabling contexts in knowledge organizations. Journal of Knowledge Management, 14(4), 592-610.

[10] Clark, J., Toms, L., \& Green, K. (2014). Market-oriented sustainability: Moderating impact of stakeholder involvement. Industrial Management \& Data Systems Industrial Management \& Data Systems, 114(1), 21-36.

[11] Chan, A., \& Wang, W. (2012). The causal relationships between aspects of customer capital. Industrial Management \& Data Systems Industrial Management \& Data Systems, $112(6), 848-865$

[12] Chen, J., \& Ching, R. (2007). The effects of Information and Communication Technology on Customer Relationship Management and customer lock-in. International Journal Of Electronic Business, 5(5), 478-498.

[13] Chun Wei Choo and Rivadavia Correa Drummond de Alvarenga Neto. (2010). "Beyond the ba: managing enabling contexts in knowledge organizations", JOURNAL OF KNOWLEDGE MANAGEMENT, VOL. 14 NO. 4 2010, pp. $592-610$.

[14] Coltman, T.R., Devinney, T.M., \& Midgley, D.F. (2010). Customer relationship management and firm performance. INSEAD Working Papers Collection, pp. 1-42.

[15] Daghfous, A., Ahmad, N., \& Angell, L. (2013). The KCRM knowledge audit: Model and case illustration. Vine, 43(2), 185-209.

[16] Day, G., Van den Bulte, C. (2002). Superiority in Customer Relationship Management: Consequences for Competitive Advantage and Performance. (Report No. 02-123), Cambridge, MA: Marketing Science Institute.

[17] Daniel D. Cox \& Scott McLeod. (2014). Social media marketing and communications strategies for School superintendents, Journal of Educational Administration, Vol. 52 No. 6, 2014, pp. 850-868.

[18] Dennis Herhausen and Marcus Schögel (2013) "Profiting from customer relationship Management The overlooked role of generative learning orientation", Management Decision Vol. 51 No. 8, 2013 pp. $1678-1700$

[19] Deshpande, R., \& Webster, F. (1989). Organizational Culture and Marketing: Defining the Research Agenda. Journal of
Marketing, (53), pp. 3-15.

[20] Eskafi, M., Hosseini, S., \& Yazd, A. (2013). The value of telecom subscribers and customer relationship management. Journal Business Process Management Journal, 19(4), 737-748.

[21] Gurjeet Kaur and R.D. Sharma. (2009). "Voyage of marketing thought from a barter system to a customer centric one", Marketing Intelligence \& Planning, Vol. 27 No. 5, 2009, pp. 567-614.

[22] Harrigan, P., Ramsey, E., \& Ibbotson, P. (2009). Investigating the e-CRM activities of Irish SMEs. Journal of Small Business and Enterprise Development, 16(3), 443-465.

[23] Harrigan, P., Ramsey, E., \& Ibbotson, P. (2012). Entrepreneurial marketing in SMEs: The key capabilities of e-CRM. Journal of Research in Marketing and Entrepreneurship, 14(1), 40-64.

[24] Herhausen, D., \& Schögel, M. (2013). Profiting from customer relationship management. Management Decision, 51(8), $1678-1700$

[25] Hwang, J., \& Kandampully, J. (2012). The role of emotional aspects in younger consumer-brand relationships. Journal of Product \& Brand Management, 21(2), 98-108.

[26] H.Y. Lam, G.T.S. Ho, C.H. Wu and K.L. Choy. (2014). Customer relationship mining system for effective strategies formulation, Industrial Management \& Data Systems, Vol. 114 No. 5, 2014, pp. 711-733.

[27] Islam, M., Yang, Y., \& Mia, L. (2012). The impact of company learning and growth capabilities on the customerrelated performance. Benchmarking: An International Journal, 19(2), 137-158.

[28] Jamali, R., Moshabaki, A., Aramoon, H., \& Alimohammadi, A. (2013). Customer relationship management in electronic environment. The Electronic Library, 31(1), 119-130.

[29] Jifeng $\mathrm{Mu}$ (2013) "Networking capability, new venture performance and entrepreneurial rent", Journal of Research in Marketing and Entrepreneurship, Vol. 15 No. 2, 2013 , pp. 101-123

[30] Kaur, G., \& Sharma, R. (2009). Voyage of marketing thought from a barter system to a customer centric one. Marketing Intelligence \& Planning, 27(5), 567-614.

[31] Kim, J., Suh, E., \& Hwang, H. (2003). A model for evaluating the effectiveness of CRM using the balanced scorecard. Journal of Interactive Marketing, 7(2), 5-19.

[32] Kim, M., Park, J., Dubinsky, A., \& Chaiy, S. (2012). Frequency of CRM implementation activities: A customercentric view. Journal of Services Marketing, 26(2), 83-93.

[33] Lado, A., Paulraj, A., \& Chen, I. (2011). Customer focus, supply-chain relational capabilities and performance. The International Journal of Logistics Management, 22(2), 202-221.

[34] Landroguez, S., Castro, C., \& Cepeda-Carrión, G. (2011). Creating dynamic capabilities to increase customer value. Management Decision, 49(7), 1141-1159.

[35] Maklan, S., \& Knox, S. (2009). Dynamic capabilities: The missing link in CRM investments. European Journal of 
Marketing, 43(11), 1392-1410.

[36] Mamoun N. Akroush , Samer E. Dahiyat , Hesham S. Gharaibeh and Bayan N. Abu-Lail, "Customer relationship management implementation An investigation of a scale's generalizability and its relationship with business performance in a developing country context", International Journal of Commerce and Management, Vol. 21 No. 2, 2011 , pp. 158-191

[37] Majidul Islam, Yi-Feng Yang and Lokman Mia. (2012). "The impact of company learning and growth capabilities on the customer-related performance", Benchmarking: An International Journal, Vol. 19 No. 2, 2012, pp. 137-158

[38] Mohammad Ali Shafia, Mohammad Mahdavi Mazdeh, Mahboobeh Vahedi and Mehrdokht Pournader (2011), "Applying fuzzy balanced scorecard for evaluating the CRM performance " Industrial Management \& Data Systems, Vol. 111 No. 7, 2011 , pp. 1105-1135

[39] Mu, J. (2013). Networking capability, new venture performance and entrepreneurial rent. Journal of Research in Marketing and Entrepreneurship, 15(2), 101-123.

[40] Ngo, L., \& O'cass, A. (2010). Value creation architecture and engineering. European Business Review, 22(5), 496-514.

[41] Nonaka, I. (1991, November-December). The Knowledge-Cr eating Company. Harvard Business Review, 69(6), 96-104.

[42] Padmavathy, C., Balaji, M., \& Sivakumar, V. (2012). Measuring effectiveness of customer relationship management in Indian retail banks. International Journal of Bank Marketing, 30(4), 246-266.

[43] Paul Harrigan, Elaine Ramsey and Patrick Ibbotson (2011) " Entrepreneurial marketing in SMEs: the key capabilities of e-CRM", Journal of Research in Marketing and Entrepreneurship , Vol. 14 No. 1, 2012 ,pp. 40-64

[44] Pennie Frow, Adrian Payne and Ian F. Wilkinson and Louise Young. (2011)."Customer management and CRM: addressing the dark side", Journal of Services Marketing, 25/2 (2011), pp.79-89.

[45] Preety Awasthi and Purnima S. Sangle. (2012). "Adoption of CRM technology in multichannel environment: a review (2006-2010)", Business Process Management Journal, Vol. 18 No. 3, 2012, pp. 445-471.

[46] Rocca, A., \& Snehota, I. (2014). Value creation and organisational practices at firm boundaries. Management Decision, 52(1), 2-17.

[47] Rostami, A., Valmohammadi, C., \& Yousefpoor, J. (2014). The relationship between customer satisfaction and customer relationship management system; a case study of Ghavamin Bank. Industrial and Commercial Training, 46(4), 220-227.

[48] Sangle, P., \& Awasthi, P. (2011). Consumer's expectations from mobile CRM services: A banking context. Business Process Management Journal, 17(6), 898-918.

[49] Sarmaniotis, C., Assimakopoulos, C., \& Papaioannou, E.
(2013). Successful implementation of CRM in luxury hotels: Determinants and measurements. EuroMed Journal of Business, 8(2), 134-153.

[50] Shafia, M., Mazdeh, M., Vahedi, M., \& Pournader, M. (2011). Applying fuzzy balanced scorecard for evaluating the CRM performance. Industrial Management \& Data Systems, 111(7), 1105-1135.

[51] Silvia Martelo Landroguez, Carmen Barroso Castro and Gabriel Cepeda-Carrio'n (2011), "Creating dynamic capabilities to increase customer value", Management Decision Vol. 49 No. 7, 2011, pp. 1141-1159.

[52] Stan Maklan and Simon Knox (2008), "Dynamic capabilities: the missing link in CRM investments", European Journal of Marketing, Vol. 43 No. 11/12, 2009, pp. 1392-1410.

[53] Stewart, G., Zacharia, Z., \& Artis, A. (2012). Leveraging relationship orientation and its impact on relationship outcomes. Journal of Business \& Industrial Marketing, 27(8), $644-658$

[54] Subba Moorthy and Douglas E. Polley. (2010). "Technological knowledge breadth and depth: performance impacts", JOURNAL OF KNOWLEDGE MANAGEMENT, VOL. 14 NO. 3 2010, pp. 359-377.

[55] Tiedemann, N., Birgele, M., \& Semeijn, J. (2009). Increasing hotel responsiveness to customers through information sharing. Tourism Review, 64(4), 12-26.

[56] Tseng, S., \& Wu, P. (2014). The impact of customer knowledge and customer relationship management on service quality. International Journal of Quality and Service Sciences, 6(1), 77-96.

[57] U-on, Vichit. (2010). Research and Information Search for Business. Sripatum Press.

[58] Ramayah, T., Samat, N., \& Lo, M. (2011). Market orientation, service quality and organizational performance in service organizations in Malaysia. Asia-Pacific Journal of Business Administration, 3(1), 8-27.

[59] Wang, Y., \& Feng, H. (2012). Customer relationship management capabilities. Management Decision, 50(1), 115-129.

[60] Wei-Tsong Wang and Hui-Min Li. (2012). "Factors influencing mobile services adoption: abrand-equityperspect ive ”, Internet Research , Vol. 22 No. 2, 2012 , pp. 142-79

[61] Yonggui Wang and Hui Feng (2013) “Customer relationship management capabilities Measurement, antecedents and consequences", Management Decision Vol. 50 No. 1, 2012 pp. $115-129$

[62] Zheng, V. (2011). The value proposition of adopting mCRM strategy in UK SMEs. Journal of Systems and Information Technology, 13(2), 223-245.

[63] Öztayşi, B., Sezgin, S., \& Özok, A. (2011). A measurement tool for customer relationship management processes. Industrial Management \& Data Systems, 111(6), 943-960. 